Natalia Grebeniuk, Oleksii Dotsenko

V.N. Karazin Kharkiv National University

4 Svobody Sq., 61022, Kharkiv, Ukraine

E-mail: nogrebenyuk@karazin.ua, psp9999psp@gmail.com

ORCID: https://orcid.org/0000-0003-0548-4772, https://orcid.org/0000-0002-2028-1810

\title{
MODERN CRYPTOGRAPHIC TOOLS FOR DOING BUSINESS
}

Not much time has passed since the advent of the first Bitcoin cryptocurrency in 2009. It was the starting point for the development of blockchain technologies. In just one decade there occurred global rethinking of this significant technology for the economy. After a long stage of testing the mentioned technology reliability, it started to be tested in various fields of industry, logistics, e-commerce and business management. Cryptographic technology is a special case of using a decentralized data registry and a mechanism of decision making and coordination without human factor participation. Thanks to this range of properties, cryptographic technologies began to expand the field of their application, diversify functions and standards, and to improve their characteristics and qualities. Directly for business, it has truly become a technology of the future. Optimization and automation of business administration and management, logistics, expansion of methods of attracting investments - all this started to be subjected to cryptographic systems control. Cryptographic technologies cause more and more changes in the work of the financial sector that leads to finding new solutions in the field of state regulation of business processes. The article considers the use of such systems in business problems solving. Descriptions of the examples of the world experience in using cryptographic systems for optimization processes are given. The main types of tokens are compared, their operation and functions are described. The arguments for the most effective further expansion of the scope of using tokens are brought forward. The developed algorithm for the implementation of cryptographic technologies in business using the example of a blockchain platform is described.

Keywords: cryptocurrency, blockchain, business processes, finance.

JEL Classification: C45, C81, E44, F20.

Н.О. Гребенюк, О.В. Доценко

Харківський національний університет імені В. Н. Каразіна

пл. Свободи, 4, м. Харків, 61022, Україна

E-mail: nogrebenyuk@karazin.ua,psp9999psp@gmail.com

ORCID: https://orcid.org/0000-0003-0548-4772, https://orcid.org/0000-0002-2028-1810

\section{СУЧАСНІ КРИПТОГРАФІЧНІ ІНСТРУМЕНТИ ДЛЯ ВЕДЕННЯ БІЗНЕСУ}

Пройшло не так багато часу з виникнення першої криптовалюти Біткоін в 2009 р. Це стало відправною точкою розвитку блокчейн технологій. Всього за одне десятиліття відбулося глобальне переосмислення цих значущих для економіки технологій. Після тривалого етапу перевірки надійності криптографічної технології, її почали тестувати в самих різних областях виробництва, логістики, електронної комерції та управління бізнесом. Технологія являє собою окремий випадок використання децентралізованого реєстру даних і механізму прийняття і узгодження рішень без втручання людського фактору. Завдяки такому спектру можливостей стало розширюватися поле застосування криптографрічних технологій, почалися диверсифікація функції і стандартів, покращення їх властивостей і якості. Безпосередньо для ведення бізнесу це стало дійсно технологією майбутнього дня. Оптимізація автоматизація бізнес адміністрування та управління, логістики, розширення методів залучення інвестицій все це почало переходити під контроль криптографічних систем. Криптографічні технології вносять все більше змін у роботу фінансового сектору, що призводить до необхідності пошуку нових рішень у сфері державного регулювання бізнес-процесів. У статті розглядається використання подібних технологій та систем для вирішення бізнес-проблем. Наведено опис прикладів світового досвіду використання криптографічних систем для процесів оптимізації. Порівнюються основні типи токенів, описується їх дія та функції. Висуваються аргументи для найбільш ефективного подальшого розширення сфери операцій із токенами. Представлено розроблений автором алгоритм впровадження криптографічних технологій у бізнесі на прикладі блокчейн платформи.

Ключові слова: криптовалюта, блокчейн, бізнес-процеси, фрінанси.

JEL Classification: C45, C81, E44, F20.

๑ Grebeniuk N., Dotsenko O., 2019 
Н.А. Гребенюк, А.В. Доценко

Харьковский национальный университет имени В. Н. Каразина

пл. Свободы, 4, г. Харьков, 61022, Украина

E-mail: nogrebenyuk@karazin.ua, psp9999psp@gmail.com

ORCID: https://orcid.org/0000-0003-0548-4772, https://orcid.org/0000-0002-2028-1810

\section{СОВРЕМЕННЫЕ КРИПТОГРАФИЧЕСКИЕ ИНСТРУМЕНТЫ ДЛЯ ВЕДЕНИЯ БИЗНЕСА}

Прошло не так много времени с возникновения первой криптовалюты Биткоин в 2009 г. Это стало отправной точкой развития блокчейн технологий. Всего за одно десятилетие произошло глобальное переосмысление этой значимой для экономики технологии. После длительного этапа проверки надежности криптографической технологии, ее начали тестировать в самых различных областях производства, логистики, электронной коммерции и управления бизнесом. Технология представляет собой частный случай использования децентрализованного реестра данных и механизма принятия и согласования решений без участия человеческого фрактора. Благодаря такому спектру возможностей начало расширяться поле применения криптографических технологий, стали диверсифицироваться функции и стандарты, улучшаться их характеристики и качества. Непосредственно для ведения бизнеса они действительно стали технологиями будущего дня. Оптимизация и автоматизация бизнес администрирования и управления, логистики, расширение методов привлечения инвестиций - всё это начало переходить под контроль криптографических систем. Криптографические технологии вносят все больше изменений в работу финансового сектора, что приводит к необходимости поиска новых решений в области государственного регулирования бизнес-процессов. В статье рассматривается использование подобных систем и технологий для решения бизнес-задач. Приводятся описания примеров мирового опыта использования криптографических систем для процессов оптимизации. Сравниваются основные типы токенов, описываются их работа и функции. Приводятся аргументы в пользу наиболее эффективного дальнейшего расширения сферы работы с токенами. Представлен разработанный автором алгоритм внедрения криптографических технологий в бизнес на примере блокчейн платформы.

Ключевые слова: криптовалюта, блокчейн, бизнес-процессы, финансы.

JEL Classification: C45, C81, E44, F20.

Introduction. We live in the world of dynamic changes in the field of innovations and technologies that facilitate the introduction of revolutionary new financial instruments, ways of doing business, of modernizing accounting and information sharing, as well as the rise of other positive phenomena.

Cryptographic technologies have become a new driver for the development of business models for a long time. More and more companies are investing their capital in improving logistics using blockchain platforms, issuing ICOs for quick fundraising, diversifying risks and improving their financial condition by investing in token assets. But, as before, the situation with the definitions and concepts of cryptographic tools remains unsolved. Today, Bitcoin's capitalization is about 135 billion dollars, which is slightly more than the budget of Ukraine amounting to 40 billion dollars (2019) (Ministry of Finance of Ukraine, 2019). The total capitalization of the crypto-assets market becomes more than $\$ 200$ billion, and gradually begins to restore growth (CoinMarketCap, 2019).

The cryptographic technology market presents great advantages in doing business, which provokes a great interest in research in this area of activity. At the given stage of cryptographic innovations development there are several fundamental problems that impede the process of innovation implementing. The most significant problems include the adjustment of legislative aspects and adaptation to the traditional systems of doing business. But the biggest problem is a lack of understanding of the fundamental differences and methods of using certain crypto assets.

Many scientists around the world have studied this topic of scientific work, including such as:', Ed. Tijan, S. Aksentijevic (Tijan et al., 2019), H. Hassani, Xu Huang, E. Silva (Hassani et al., 2018), J. Agajo (Agajo et al., 2019), S.M. Avdoshin (Avdoshin \& Savelyeva, 2006), I.P. Novikov (Novikov et al., 2017), A.V. Babkin (Babkin et al., 2017).

The object-matter of this research is learning innovative methods of doing business using cryptographic technologies.

The subject-matter of the research is functional features of existing crypto assets and their practical application in doing business. 
The objective of the research is to develop an algorithm for implementing cryptographic systems to optimize the business in Ukraine. In accordance with the subject and the specified above objective of the study, we set the following tasks:

to consider the existing types of cryptocurrencies and tokens, systematizing them according to the functional features;

to analyze the global experience of using crypto technologies in different business areas;

to create algorithm for implementation crypto technologies in doing business on the example of the blockchain platform.

The methodological grounds of the study are the historical and systematic approaches, general finance theory fundamental provisions, sustainable development concept, as well as the applied research methods: comparative, system-structured analysis, statistical and factor analysis.

Results of the research. Almost 10 years have passed since the release of the first protocol of a blockchain and the first world decentralized cryptocurrency. Bitcoin is the first such an equivalent as well as the first ever popular prototype of cryptocurrencies. Cryptocurrencies have a number of advantages in electronic accounts, such as the speed of transactions and the endless process of splitting a whole unit of currency. With this function, we can realize the absolute equivalent between any values, both infinitesimal and large. Over time, new unique types of currencies emerged. Some have historically begun to be used in tight closed systems and functioned as specific cryptographic assets that are classified according to their scope.

The classification of crypto-assets has very extensive systems (fig. 1.). In terms of market capital ratings, $\mathrm{BTC}, \mathrm{XRP}$ and $\mathrm{BCH}$ dominate payment / value storage, whereas platform tokens such as ETH and EOS are dominated by smart contracts and decentralized applications (DApp). Of the 200 most popular crypto assets by market maximum, security assets account for about half. The growing number of token assets and securities remains very small (only 3\%) (Crypto Compare, 2018).

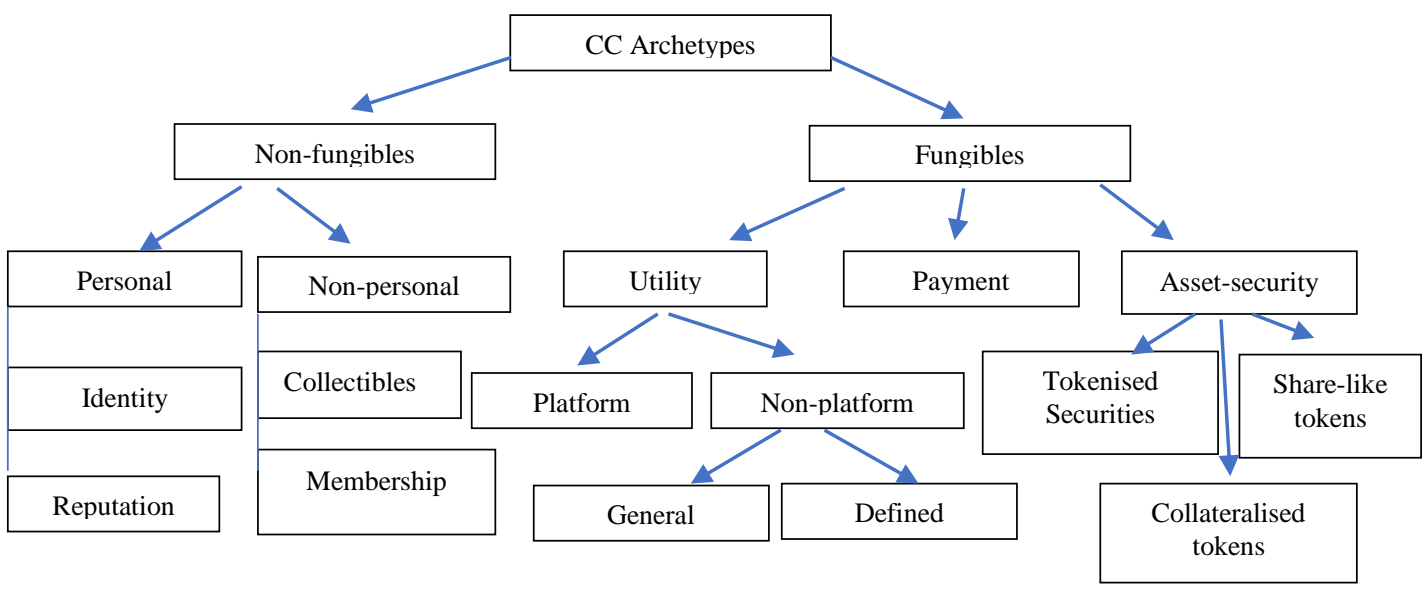

Fig. 1. Classification of cryptocurrency assets by archetypes

Source: (Crypto Compare, 2018)

Although utility tokens exhibit less market capitalization than payment-based crypto-assets, they are much larger and have a wide range of uses. Most utility tokens are platform-based and designed for a specific network. Most higher-end non-platform utility tokens use Ethereum (ETH) as their smart contract platform (Avdoshin \& Savelyeva, 2006).

The classification given is quite extensive and detailed. In general, the main three branches of tokens can be distinguished. The first - «Cryptocurrencies» - characterizes the crypto-asset used for the measure of value and payment, compared to the function of electronic currencies. Examples of the first type are Bitcoin (BTC), Litecoin (LTC), Dash (DASH). The second is "Cryptocommodities», which are used to access digital resources, such as cloud storage. Examples of the second type are: Golem (GNT) for CPU Power, Storj (STORJ) for Cloud Storage, Ethereum (ETH) for Smart Contracts. And last, "Cryptotokens», which describes the digital equivalent of specific products, 
services, or resources on specific platforms. examples of the third type: Gnosis (GNO) for Prediction Markets, Digix (DGX) for Gold-backed token.

About $54 \%$ of crypto-assets are centralized systems. About $30 \%$ is decentralized, and other systems combine mixed principles. Most of the centralized systems are financial cryptographic assets (Crypto Compare, 2018).

In terms of industry classification, financial and insurance crypto-assets dominate the cryptoasset ecosystem. The ONS (Object Name Service) industry standard classification was applied to up to $75 \%$ of cryptocurrencies when taxed. The rest were categorized as "Blockchain application specific". The vast majority of cryptocurrencies were financial and insurance related (40\% of the total). About $23 \%$ of financial service providers operate on Blockchain platforms (fig. 2.). Cryptocurrencies in the financial and insurance sectors tend to have higher market capitalization than other industry classifications (Deloitte, 2018).

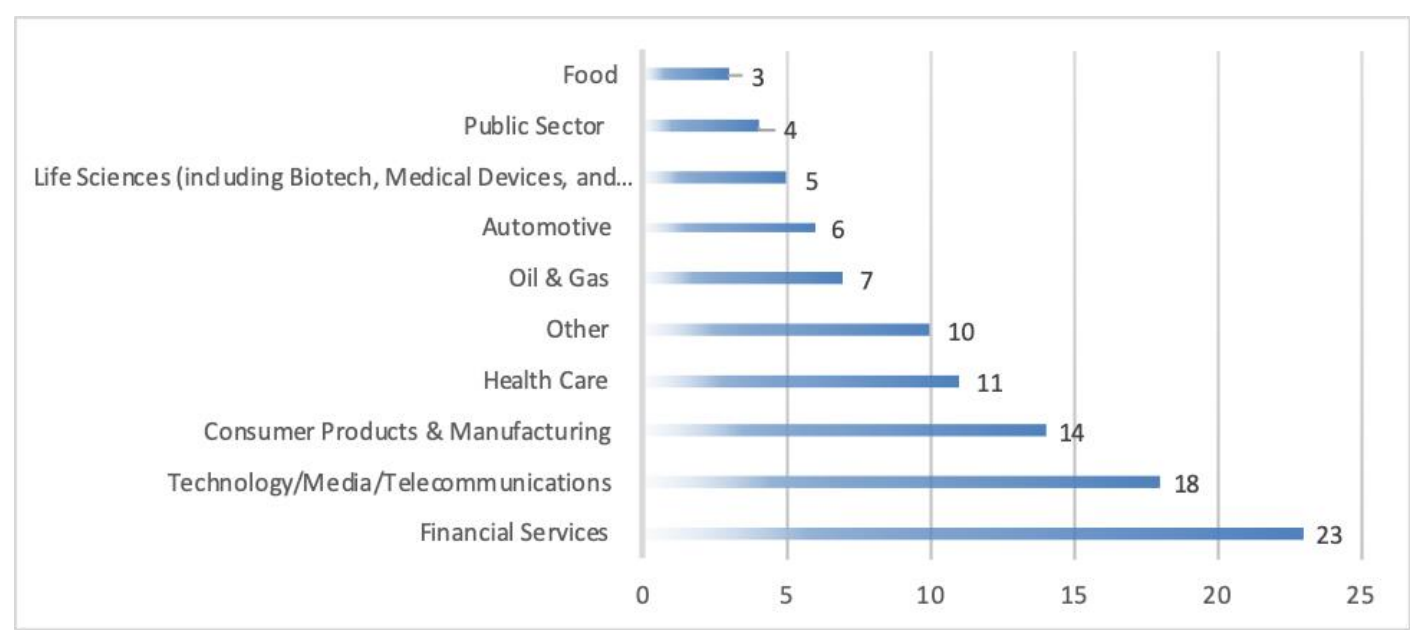

Fig. 2. Applications of the blockchain protocol

Source: (Deloitte', 2018)

According to the FINMA guidelines, at least $54.8 \%$ of publicly placed crypto assets are considered securities (Crypto Compare, 2018). Most crypto assets are centralized in one form or another; this trend is driven by the increasing centralization of non-platform tokens that are focused on serving a particular network. Cryptographic payments show a much lower concentration of property levels than utility tokens and security tokens. Tokens for the prediction and trading markets represent the most concentrated use cases of utility tokens. Crypto-assets using decentralized network servers (DASH, NEM) show a significant difference in the distribution of property compared to other crypto-assets.

According to the data structure, just under half of all cryptocurrencies in the study were created using the ERC-20 protocol built on the Ethereum platform. Approximately $9 \%$ of all tokens were based on non-Ethereum blockchains.

Especially here such countries as Ukraine, Poland, as well as the Baltic countries, Belarus stand out. In particular, Ukraine is among the top three countries in the number of IT specialists, and has long taken its place in the global division of labor in this innovative sphere. Many even prophesy her world leadership in this area in the near future (Kim, 2018).

Ukraine is in the TOP-10 countries in the number of Bitcoin users (Ukraine Digital News, 2018). In Ukraine, its activity is the largest in the CIS, the bitcoin agency Kuna (Kuna Fintech Limited, 2018), one of the projects of which is the cryptocurrency exchange. Large development and research companies, such as the Distributed Lab (Distributed Lab, 2019), also operate here.

The use of decentralized technologies is planned and partially implemented already at the state level: e-Auction 3.0, e-Vox (e-Vox, 2019), E-Ukraine (E-Ukraine, 2019). The cryptocurrency community in Ukraine is also very developed. Also, there are several examples of world experience 
in using cryptographic systems for optimization processes. Examples include projects such as: GEO Protocol (GEO Protocol, 2019), Remme (Remme, 2019), Hacken (Hacken, 2019) and others.

For the development of the entire economy, it is necessary that more companies of both large concerns and small companies introduce this technology. Having studied the world experience and systematized it to simplify the process and reduce the implementation time, we offer a step-by-step description of this procedure. We propose an algorithm based on the analysis of the following works by scientists such as: Ed. Tijan and S. Aksentijevic' (Tijan et al., 2019), H. Hassani, Xu Huang, E. Silva (Hassani et al., 2018), J. Agajo (Agajo et al., 2019). To implement cryptographic technologies in business processes, the following work algorithm is proposed:

a) Set a goal. The first step is to achieve your core business goal. If you know why you really need a blockchain, you are more likely to succeed in finding a solution.

b) Think about the benefits. In other words, try to answer the following question: what would I benefit from this? It makes no sense to include blockchain in your business if you cannot determine the benefits of this move.

c) Create a structure. The main decisions you need here are: consensus rules, data privacy for book users, a set of algorithms to run.

d) Development of a roadmap. Make sure it contains the following items:

Description of Minimum Viable Product (MVP).

Full Feature Product Description (FFP).

Characteristics of the platform. Here you can specify the platform used to create the MVP.

Product design and prototyping.

Possible / actual review of issues.

Make a list of the problems you encountered while developing a full-fledged product.

e) Choose a platform to integrate blockchain technology into your business.

f) Implement the concept.

g) Add use cases. Think about the possible ways to use blockchain in your business. This will help you better understand the main pros and cons of your concept.

Conclusions. Having conducted the research, the following conclusions have been made:

- Certainly, the field of cryptographic technologies is one of the most promising and has great prospects in using.

- The main reason for the various approaches to crypto assets classification is their special properties and features of their functionality.

- There are many types of cryptographic assets that make it possible to use these technologies in various fields of business activity.

- It's very important for a business to implement technology as quickly as possible in order to earn extra profits.

- The topic is very extensive and requires further expansion and in-depth study.

\section{References}

1. Capitalization cryptocurrency market by CoinMarketCap. Retrieved from https://coinmarketcap.com.

2. Implementation of the state budget of Ukraine 2019. Ministry of Finance of Ukraine. Retrieved from https://index.minfin.com.ua/finance/budget/gov/. (In Ukrainian)

3. Tijan, E., Aksentijevic,' S., Ivanic, K. and Jardas M. (2019). Blockchain Technology Implementation in Logistics. Sustainability 2019, 11, 1185. doi:10.3390/su11041185.

4. Hassani, H., Huang, Xu and Silva, E. (2018). Big-Crypto: Big Data, Blockchain and Cryptocurrency. Big Data Cogn. Comput, 2, 34. doi:10.3390/bdcc2040034.

5. Agajo, J., Adewale Ajao, L., Adewale Adedokun, E. and Karngong, L. (2019) Crypto Hash AlgorithmBased Blockchain Technology for Managing Decentralized Ledger Database in Oil and Gas Industry. Multidisciplinary Scientific Journal, 2, 300-325. doi:10.3390/j2030021.

6. Avdoshin, S.M., Savelyeva A.A. (2006). Cryptographic methods for protecting information systems. News AIN them. A.M. Prokhorov. Business Informatics, 17, 91-99. Retrieved from https://www.hse.ru/data/005/621/1235/001.pdf. (In Russian)

7. Vlasov A.I., Karpunin A.A., Novikov I. P. (2017). System analysis of blockchain data exchange and storage technology. Retrieved from https://cyberleninka.ru/article/n/sistemnyy-analiz-tehnologii-obmena-ihraneniya-dannyh-blockchain. (In Russian)

8. Babkin A.V., Burkaltseva D.D., Pshenichnikov V.V., Tyulin A.S. (2017). Cryptocurrency and blockchain technology in the digital economy: the genesis of development. Scientific and technical statements of SPbSPU. 


\begin{tabular}{llccc}
\hline $\begin{array}{l}\text { Economic } \\
\text { https://economy.spbstu.ru/userfiles/files/articles/2017/5/01 }\end{array}$ babkin burkaltseva pshenichnikov tyulin.pdf. (In Russian) & from \\
\hline
\end{tabular}

9.Cryptoasset Taxonomy Report 2018. Retrieved from

https://www.cryptocompare.com/media/34478555/cryptocompare-cryptoasset-taxonomy-report-2018.pdf.

10.Breaking blockchain open Deloitte's 2018 global blockchain survey. Retrieved from https://www2.deloitte.com/content/dam/Deloitte/us/Documents/financial-services/us-fsi-2018-global-blockchainsurvey-report.pdf.

11. John Sung Kim. (2018). Ukraine Is The Best Kept Secret In California's Startup Scene. Retrieved from https://www.forbes.com/sites/forbestechcouncil/2018/10/16/ukraine-is-the-best-kept-secret-in-californias-startupscene/\#779e540c7ebc.

12. Official site of the Ukraine Digital News. Retrieved from https://www.uadn.net/2018/05/31/ukraineamong-top-10-countries-by-the-number-of-cryptocurrency-users/.

13.Official site of Kuna Fintech Limited. Retrieved from https://kuna.io.

14.Official site of Distributed Lab. Retrieved from https://distributedlab.com.

15.Official site of e-Vox: an open platform for e-democracy. Retrieved from http://ukr.e-vox.org.

16. Official site of Portal development of e-democracy. Retrieved from https://eukraine.org.ua/ua.

17. Official site of the GEO Protocol project. Retrieved from https://www.geoprotocol.io.

18.Official site of the Remme project. Retrieved from https://remme.io.

19.Official site of the Hacken project. Retrieved from https://hacken.io.

\section{Література}

1. Capitalization cryptocurrency market by CoinMarketCap. URL: https://coinmarketcap.com.

2. Виконання державного бюджету України в 2019 р. Міністерство фрінансів України. URL: https://index.minfin.com.ua/finance/budget/gov/.

3. Tijan E., Aksentijevic' S., Ivanic K. and Jardas M. Blockchain Technology Implementation in Logistics. Sustainability. 2019, Vol. 11, 1185. doi:10.3390/su11041185.

4. Hassani H., Huang Xu and Silva E. Big-Crypto: Big Data, Blockchain and Cryptocurrency. Big Data Cogn. Comput. 2018, Vol.2, 34. doi:10.3390/bdcc2040034.

5. Agajo J., Adewale Ajao L., Adewale Adedokun E. and Karngong L. Crypto Hash Algorithm-Based Blockchain Technology for Managing Decentralized Ledger Database in Oil and Gas Industry. Multidisciplinary Scientific Journal. 2019. Vol. 2. P. 300-325. doi:10.3390/j2030021.

6. Авдошин С.М., Савельева А.А. Криптографические методы защиты информационных систем. Известия АИН им. А.M. Прохорова. Бизнес-информатика. 2006. T. 17, C. 91-99. URL: https://www.hse.ru/data/005/621/1235/001.pdf

7. Власов А.И., Карпунин А.А., Новиков И. П. Системный анализ технологий обмена и хранения данных BLOCKCHAIN. 2017. URL: https://cyberleninka.ru/article/n/sistemnyy-analiz-tehnologii-obmena-ihraneniya-dannyh-blockchain.

8. Бабкин А. В., Буркальцева Д.Д., Пшеничников В.В., Тюлин А.С. Криптовалюта и блокчейн технология в цифровой экономике: генезис развития. Научно-технические ведомости СПбГПУ. Экономические науки. T. 10, № 5, 2017, C. 9-22. URL:

https://economy.spbstu.ru/userfiles/files/articles/2017/5/01 babkin burkaltseva pshenichnikov tyulin.pdf

9. Cryptoasset Taxonomy Report 2018. URL:

https://www.cryptocompare.com/media/34478555/cryptocompare-cryptoasset-taxonomy-report-2018.pdf.

10. Breaking blockchain open Deloitte's 2018 global blockchain survey. URL:

https://www2.deloitte.com/content/dam/Deloitte/us/Documents/financial-services/us-fsi-2018-global-blockchainsurvey-report.pdf.

11. John Sung Kim. Ukraine Is The Best Kept Secret In California's Startup Scene. 2018. URL: https://www.forbes.com/sites/forbestechcouncil/2018/10/16/ukraine-is-the-best-kept-secret-in-californias-startupscene/\#779e540c7ebc.

12. Official site of the Ukraine Digital News. URL: https://www.uadn.net/2018/05/31/ukraine-among-top-10countries-by-the-number-of-cryptocurrency-users/.

13.Official site of Kuna Fintech Limited. URL: https://kuna.io.

14.Official site of Distributed Lab. URL: https://distributedlab.com

15.Official site of e-Vox: an open platform for e-democracy. URL: http://ukr.e-vox.org.

16.Official site of Portal development of e-democracy. URL: https://eukraine.org.ua/ua

17. Official site of the GEO Protocol project. URL: https://www.geoprotocol.io

18. Official site of the Remme project. URL: https://remme.io.

19.Official site of the Hacken project. URL: $\underline{\text { https://hacken.io. }}$ 